November 2021

\title{
Effectiveness of Group Work Contracts to Facilitate Collaborative Group Learning and Reduce Anxiety in Traditional Face-to-Face Lecture and Online Distance Education Course Formats
}

\author{
Sydney F. Brannen \\ University of Guelph, sydneybrannen@gmail.com \\ David Beauchamp \\ University of Guelph, dbeaucha@uoguelph.ca \\ Nadia M. Cartwright \\ University of Guelph, cartwrin@uoguelph.ca \\ Danyelle M. Liddle \\ University of Guelph, dliddle@uoguelph.ca \\ Justine M. Tishinsky \\ University of Guelph, jtishins@uoguelph.ca
}

See next page for additional authors

Follow this and additional works at: https://digitalcommons.georgiasouthern.edu/ij-sotl

\section{Recommended Citation}

Brannen, Sydney F.; Beauchamp, David; Cartwright, Nadia M.; Liddle, Danyelle M.; Tishinsky, Justine M.; Newton, Genevieve; and Monk, Jennifer M. (2021) "Effectiveness of Group Work Contracts to Facilitate Collaborative Group Learning and Reduce Anxiety in Traditional Face-to-Face Lecture and Online Distance Education Course Formats," International Journal for the Scholarship of Teaching and Learning: Vol. 15: No. 2, Article 5.

Available at: https://doi.org/10.20429/ijsotl.2021.150205 


\title{
Effectiveness of Group Work Contracts to Facilitate Collaborative Group Learning and Reduce Anxiety in Traditional Face-to-Face Lecture and Online Distance Education Course Formats
}

\begin{abstract}
Group work (GW) in undergraduate education facilitates the development of communication and collaborative skills. However, dysfunctional and inequitable group dynamics can have adverse effects, leading to increased anxiety. This research sought to determine the effectiveness of a Group Work Contract to facilitate the GW process in the face-to-face $(n=168)$ and online $(n=105)$ formats of a third year nutritional science course. Changes in students' attitudes and approaches to GW were assessed before (semester week 4) and after (semester week 12) completion of the contract and assignment via online surveys. The results in both course formats were similar, wherein the Group Work Contract reduced student anxiety and improved group dynamics and communication between group members, resulting in an improved learning experience overall . Further, the preferred methods of GW online communication utilized social networking platforms. This data demonstrates the benefits of formally structuring the GW process to optimize the student learning experience.
\end{abstract}

\section{Keywords}

Group work contract, online learning, group work dynamics, student anxiety, distance education

Creative Commons License

(c) $($ ) $\ominus$

This work is licensed under a Creative Commons Attribution-Noncommercial-No Derivative Works 4.0 License.

\section{Cover Page Footnote}

This project was supported by the COESP BioEd Research Grant awarded to J.M.M. D.B. was supported by the Scholarship of Teaching and Learning Graduate Research Assistantship from the College of Biological Sciences at the University of Guelph. N.M.C was supported by an Undergraduate Research Assistantship from the University of Guelph. D.M.L was supported by a NSERC graduate scholarship.

\section{Authors}

Sydney F. Brannen, David Beauchamp, Nadia M. Cartwright, Danyelle M. Liddle, Justine M. Tishinsky, Genevieve Newton, and Jennifer M. Monk 


\title{
Effectiveness of Group Work Contracts to Facilitate Collaborative Group Learning and Reduce Anxiety in Traditional Face-to-Face Lecture and Online Distance Education Course Formats
}

\author{
Sydney F. Brannen, David Beauchamp, Nadia M. Cartwright, Danyelle M. Liddle, \\ Justine M.Tishinsky, Genevieve Newton, and Jennifer M. Monk \\ University of Guelph
}

Received: I5 November 2020;Accepted: 27 May 202I

\begin{abstract}
Group work (GW) in undergraduate education facilitates the development of communication and collaborative skills. However, dysfunctional and inequitable group dynamics can have adverse effects, leading to increased anxiety. This research sought to determine the effectiveness of a Group Work Contract to facilitate the GW process in the face-to-face $(n=168)$ and online $(n=105)$ formats of a third year nutritional science course. Changes in students' attitudes and approaches to GW were assessed before (semester week 4) and after (semester week 12) completion of the contract and assignment via online surveys. The results in both course formats were similar, wherein the Group Work Contract reduced student anxiety and improved group dynamics and communication between group members, resulting in an improved learning experience overall . Further, the preferred methods of GW online communication utilized social networking platforms. This data demonstrates the benefits of formally structuring the GW process to optimize the student learning experience.
\end{abstract}

\section{INTRODUCTION}

Group work (GW) is an essential component in undergraduate education intended to facilitate the development of students' communication, professionalism, and co-operative work skills (Burdett, 2003; Volkov \& Volkov, 20I5). Further, universities have seen an increase in the need to develop students' experiences in GW in order to enhance their graduates' compatibility and employability in the workforce (Burdett, 2003; Eurofound, 2007; Gil \& Alcover, 2008). GW, therefore, serves multiple purposes; to develop collaborative skills and build academic knowledge (Y. Chang \& Brickman, 20I8; Gillies, 2003; Wasley, 2006), promote scientific literacy (Auerbach \& Schussler, 20I7; Liu et al., 2019; Mclnerney \& Fink, 2003; Monk \& Newton, 2018) and communication skills (Curșeu et al., 20I2) while providing students with the opportunity to initiate, form and maintain social educational relationships (Payne, et al., 2006). However, working in groups can be associated with inherent difficulties, as each member comprising the group may be entering with different levels of organizational skills, time management skills, and degrees of commitment (Burdett, 2003 Butt, 2017). Further, members of the group may have various levels of anxiety surrounding the desired grades for the task assigned, which could lead to disputes between individuals (Butt, 2017).

From the perspective of the student completing the assignment, GW can be broken into several components, where some aspects are perceived as positive, and others perceived as negative (Burdett, 2003). Overall, the positive aspects of GW have been described as the ability to share and generate new ideas, meet other people with similar interests, and divide the required workload (Hammar Chiriac, 20 14; Wilson et al., 20I8). In contrast, the negative aspects of GW are poor collaboration skills, the inequitable distribution of effort, differing perceptions of work quality between group members, difficulty accommodating the schedules of multiple individuals, ineffective communication, and a lack of staff support for conflict resolution (Burdett, 2003; Freeman \& Greenacre, 20 I0; Janssen et al., 2007; Le, Janssen, \&Wubbels, 20 I6; Li \& Campbell, 2008; Livingstone \& Lynch, 2000; Pauli et al., 2008). Further, many students experience anxiety about GW assignments, in particular the impact of other students less engaged in the group assignment on their grade (Butt, 2017; Chang \& Brickman, 20 I8; Cooper et al., 2018). Ultimately, students' perceptions about
GW can be dependent upon whether the group performs well or poorly on the assignment (Chang \& Brickman, 20I8).

One approach to increase accountability in GW is to include a peer-evaluation of each group member, thereby ensuring that final marks on the group assignment are better aligned with individual students' effort or contribution (Burdett, 2003). Peer evaluations have been shown to help equalize the distribution of work between group members (Brooks \& Ammons, 2010; Cestone et al., 2008) and to have a positive effect on students' perceptions about GW (Brooks \& Ammons, 20 I0). Another approach is the implementation of a Group Work Contract, which has been utilized previously to help structure the group learning experience (Cartwright et al., 2020; Chang \& Brickman, 20 I8; Ribner, 1974; Volet \& Mansfield, 2006; Zhang et al., 20I8). Group Work Contracts have been shown to improve clarification of appropriate behaviour expectations and collaboration, promoting students' positive attitudes towards their group, and increased individual engagement and participation in the group activity (Ribner, 1974; Zhang et al., 20l8). Developing negotiation and conflict resolution skills are important components of collaboration, and a Group Work Contract can help structure the GW process provides an opportunity to develop and utilize these skills. In this context, a Group Work Contract can facilitate the interaction between students, outline a procedure for resolving conflicts and eliminate non-functional behaviour (Cartwright et al., 2020; Ribner, 1974), thereby permitting a group learning activity to serve as a vehicle for critical skill development (Johnson et al., 2007). Combining a Group Work Contract with peer evaluations following GW, has been shown to structure the GW process and increase student accountability (Chang \& Brickman, 20 I8; Ribner, 1974).

Previously it has been shown that students in online courses conducting GW tend to be less satisfied with the overall experience, and have a more negative perception, than those conducting GW in a traditional face-to-face course format (Smith et al., $20 \mathrm{II}$ ). With the increase in popularity of online classes (Allen \& Seaman, 20I5), performing GW without the physical presence of group members in distance education (DE) courses may present an additional challenge as students may be in different time 
zones leading to increased difficulty in setting deadlines, while concomitantly increasing the anonymity of group members and consequently decreasing their sense of accountability (Chang \& Kang, 2016). Furthermore, the lack of visual cues and body language in online communication that are present in in-person meetings may also represent a communication obstacle, as different communication skills must be developed for online versus in-person communication formats (Chang \& Kang, 2016). Prior to the COVID-I 9 pandemic an increasing number of students were utilizing online learning (Wei \& Chou, 2018), which has now dramatically increased since undergraduate education has primarily moved to online learning and in-person communication options are precluded (Dhawan, 2020; Marinoni et al., 2020). With the multiple platforms available for online communication (e.g., email, sharable group documents, social networking platforms, text and group messaging apps and video conferencing) it is important to learn which communication platforms are being utilized by students. Therefore, the GW experience may differ between traditional in-person courses and online DE courses

There are several differences that are important to note between online DE and face-to-face synchronous course formats. In DE course formats learning is asynchronous, wherein students can access course material and learn without having to attend weekly lectures (Lei \& Gupta, 2010). In DE courses, optimal learning relies upon the student's drive to engage with the material and maintaining self-efficacy and independent learning skills are important for success (Brubacher \& Silindar, 2019; Zhu et al., 2020), as students who fail to schedule their time appropriately in online classes are at a higher risk of failure (Bol \& Garner, 20I I; Brubacher \& Silindar, 2019). The benefits of online DE learning include a student-driven independent pace of learning, greater flexibility in scheduling, and a lack of distractions from other students during lectures (Ekmekci, 2015; Hassenburg, 2009; Lei \& Gupta, 2010). Furthermore, greater flexibility in the course schedule in DE courses can enhance the access to education for students who may have difficulties in physically attending lectures on campus (Ekmekci, 20 I5; Hassenburg, 2009). Conversely, some disadvantages associated with DE learning can stem from the separation of teaching and learning, as communication between instructors and students can be delayed or compromised in DE courses versus traditional in-person lectures (Hassenburg, 2009).

Therefore, the aim of this study was to determine the effectiveness of a Group Work Contract in facilitating a collaborative and positive GW experience for students' and the impact on students anxiety levels associated with GW, which was assessed in both the traditional synchronous face-to-face and the asynchronous online DE course formats of a third year undergraduate nutritional science course. As a secondary objective we determined both the amount of GW communication that is performed in-person versus online, and the preferred modes of online communication utilized by students.

\section{METHODS}

\section{Participants and GW assignments}

Participants were undergraduate students enrolled in the course Fundamentals of Nutrition (NUTR*3210) at the University of Guelph. The course was taught in the traditional face-to-face lecture format in the Fall 2019 semester, and in an online DE format in the Winter 2020 semester, which are the academic semesters when these course different course formats are offered.
The number of students per group was arbitrarily determined by the course instructors. In both course formats students completed a collaborative group project, with three to four students per group, that required the integration of course concepts and information to solve problems while building scientific literacy, communication and knowledge translation skills that took the form of an infographic in the face-to-face course and a case study assignment in the DE course. In both courses the collaborative project was worth $10 \%$ of the final grade. Further, in both course formats the GW experience included the use of a Group Work Contract to help facilitate the development of positive group dynamics (Supplemental Materials) that was completed prior to the start of the group assignment. The Group Work Contract consisted of questions generated by the research team intended to facilitate the GW process by prompting students to develop a plan for the distribution of work, and a timeline for completing the assignment components in an organized manner with a professional group dynamic.After the group assignment was submitted for grading, students completed an anonymous peer-evaluation, wherein students graded their group members on the contribution of their ideas, the quality, accuracy and reliability of their work, and an overall performance on a scale of 0-5 marks ranging from no participation to a superior contribution. The outcome of the peer-evaluation contributed to $5 \%$ of students' final grade in the face-to-face and $2 \%$ of the final grade in the DE course format. It is important to note that the survey questions (outlined below) were centered directly on the influence of the Group Work Contract on the overall GW experience.

A notable difference in the structure of the GW assignments between course formats was the manner in which students were assigned to their groups. Students in the DE course format were randomly assigned by the instructor (i.e. instructor-selected), which resulted in $97 \%$ of students not knowing any of their group members and $3 \%$ of students randomly assigned to a group where they already knew at least one of their group members. Conversely, in the face-to-face course format students were permitted to select their own group members which resulted in $68 \%$ of students already knowing at least one member of their group prior to conducting the group assignment and $32 \%$ of students not knowing any other group members prior to working on the group assignment.

\section{GW surveys}

In both course formats students were invited by email (through a private link) to complete two online surveys, which were administered using the Qualtrics Insight Platform. The Pre-GW Survey was completed prior to completing the Group Work Contract and starting the GW assignment during week 4 of the semester. During week 12 of the semester, following the submission of the GW assignment and the completion of the GW peer-evaluation, students were invited to complete the Post-GW Survey. Changes in the aggregate response to each survey question over the course of the academic semester were recorded (i.e. Post-GW Survey - Pre-GW Survey). In the Pre-GW Survey, students were instructed to reflect on their previous experiences conducting GW, whereas in the Post-GW Survey, students were instructed to reflect on their experiences in engaging in the group assignment in NUTR*3210 (face-to-face or DE format). In both surveys students were asked questions pertaining to their attitudes and approaches related to group learning and group dynamics that 
were developed from the validated GW Survey published previously (Burdett, 2003) and utilized elsewhere (Cartwright et al., 2020). These questions utilized a 5-point Likert scale (I "strongly disagree", 2 "somewhat disagree", 3 "neither agree nor disagree", 4 "somewhat agree" and 5 "strongly agree").Additionally, students were asked researcher generated questions about their communication and interactions with their group members and their academic and social interaction anxiety experiences associated with GW that also utilized the 5-point Likert scale. Finally, students were asked open-ended questions about i) the proportion of GW communication that was conducted in-person versus online, ii) their preferred methods or platform for online GW communication, and iii) the underlying sources of anxiety associated with GW. Only students who completed both the Pre-GW and Post-GW Surveys were included in the analysis, specifically $n=168$ in the face-to-face course (reflective of $80 \%$ participation) and $n=105$ in the DE course (reflective of $79 \%$ participation). As an incentive to complete the surveys, students in both course formats were awarded a $1 \%$ bonus on their midterm exam grade for completing the Pre-GW Survey and a $1 \%$ bonus on their final exam grade for completing the Post-GW Survey. Students had the option of completing each online survey or an alternative assignment to receive the participation incentive. All participating students provided informed consent for participation in the study, and the research was approved by the University of Guelph Research Ethics Board (REB\#19-07-003)

\section{Statistics}

All data were analyzed using GraphPad Prism 8.2.0 (GraphPad Software, Inc., La Jolla, CA, USA) and SPSS (IBM SPSS Statistics for Macintosh, Version 26.0., Armonk, NY, USA). The alpha (0.05. Values are expressed as means \pm SEM.The assumption of normality was assessed using the Shapiro-Wilk test. Paired t-tests using a significance level of $\alpha=0.05$ were used to determine the changes across time (i.e. changes between the Pre-GW and Post-GW Surveys) within each course format. Unpaired t-tests were used to determine differences between the face-to-face and DE course formats.

\section{RESULTS \\ Changes in students' perceptions and approaches towards GW in the face-to-face and online DE course formats}

In the face-to-face course format, $66 \%$ of students were enrolled in their fifth semester, whereas $59 \%$ of students were enrolled in their fourth semester of an eight semester undergraduate program. The change in students' perceptions and approaches towards GW (i.e. the change between the Pre- and Post-GW Surveys) in both the face-to-face and online course formats, influenced by the use of a Group Work Contract are shown in Table I.These results were categorized according to changes during the academic semester in i) group dynamics, ii) communication, and iii) distribution of effort, which represent common challenges when conducting GW.

Within both course formats the implementation of a Group Work Contract improved students' perceptions about group dynamics in a similar manner.The use of a Group Work Contract helped to structure group dynamics by improving students perceptions of i) establishing positive working relationships with group members, ii) the reliability of group members, and iii) group members' interactions that were inclusive and respectful of each other's ideas $(p<0.05)$. Conversely, in both course formats there was no difference in students' perceptions of taking a leadership role during $\mathrm{GW}(p>0.05)$. When assessing the magnitude of the change between the Pre-GW and Post-GW Surveys for each of the group dynamics parameters assessed students in the DE course showed significantly greater improvement in their ability to establish positive working relationships with their group members as a result of utilizing the Group Work Contract $(p=0.05)$, which was I.5-fold higher compared to the improvement observed

\begin{tabular}{|c|c|c|c|c|c|c|c|}
\hline \multirow{2}{*}{\multicolumn{8}{|c|}{ Table I. Changes in students' professional behaviours and approaches towards GW in both the face-to-face and DE course formats }} \\
\hline & \multicolumn{3}{|c|}{ Face-to-face Format } & \multicolumn{3}{|c|}{ DE Format } & \\
\hline Survey Question & $\begin{array}{l}\text { Mean Pre-GW } \\
\text { Survey Score }\end{array}$ & $\begin{array}{c}\text { Mean Post-GW } \\
\text { Survey Score }\end{array}$ & $\begin{array}{l}\text { Mean } \\
\text { Change }\end{array}$ & $\begin{array}{l}\text { Mean Pre-GW } \\
\text { Survey Score }\end{array}$ & $\begin{array}{l}\text { Mean Post-GW } \\
\text { Survey Score }\end{array}$ & $\begin{array}{l}\text { Mean } \\
\text { Change }\end{array}$ & $\begin{array}{l}\text { Face-to- } \\
\text { face vs. DE } \\
\text { Format }\end{array}$ \\
\hline \multicolumn{8}{|l|}{ Group Dynamics } \\
\hline I assumed a leadership role & $3.85(0.06)$ & $3.83(0.06)$ & -0.02 & $3.97(0.09)$ & $3.8 I(0.10)$ & -0.16 & $p=0.11$ \\
\hline $\begin{array}{l}\text { Working in a group often required less work of } \\
\text { myself overall }\end{array}$ & $2.76(0.09)$ & $3.71(0.09)$ & $+0.95^{*}$ & $2.42(0.12)$ & $3.23(0.13)$ & $+0.8 I^{*}$ & $p=0.23$ \\
\hline $\begin{array}{l}\text { I established positive working relationships with } \\
\text { group members }\end{array}$ & $3.94(0.06)$ & $4.42(0.07)$ & $+0.48^{*}$ & $3.78(0.09)$ & $4.49(0.08)$ & $+0.7 I^{*}$ & $P=0.05$ \\
\hline Group members were reliable & $3.53(0.07)$ & $4.33(0.08)$ & $+0.80^{*}$ & $3.32(0.10)$ & $4.24(0.10)$ & $+0.92^{*}$ & $p=0.26$ \\
\hline $\begin{array}{l}\text { Group members were inclusive and respectful of } \\
\text { each other's ideas }\end{array}$ & $4.17(0.06)$ & $4.60(0.06)$ & $+0.43^{*}$ & $4.23(0.08)$ & $4.63(0.08)$ & $+0.40^{*}$ & $p=0.42$ \\
\hline $\begin{array}{l}\text { The distribution of work was fair or equitable } \\
\text { between all group members }\end{array}$ & $3.37(0.09)$ & $4.01(0.09)$ & $+0.64^{*}$ & $3.22(0.13)$ & $3.82(0.12)$ & $+0.60^{*}$ & $p=0.39$ \\
\hline I completed the majority of the work & $3.50(0.07)$ & $3.01(0.09)$ & $-0.49 *$ & $3.80(0.08)$ & $3.09(0.10)$ & $-0.7 I^{*}$ & $p=0.01$ \\
\hline \multicolumn{8}{|l|}{ Communication } \\
\hline $\begin{array}{l}\text { There were frequent and/or regular group } \\
\text { communication }\end{array}$ & $3.79(0.08)$ & $4.33(0.07)$ & $+0.54^{*}$ & $3.70(0.10)$ & $4.35(0.10)$ & $+0.65^{*}$ & $p=0.26$ \\
\hline $\begin{array}{l}\text { I experienced fewer problems (e.g. interpersonal } \\
\text { disputes, incomplete work, etc.) while } \\
\text { conducting group work }\end{array}$ & $2.91(0.08)$ & $1.95(0.09)$ & $-0.96 *$ & $3.03(0.11)$ & $2.18(0.12)$ & $-0.85^{*}$ & $p=0.26$ \\
\hline $\begin{array}{l}\text { The group worked collaboratively to solve } \\
\text { problems }\end{array}$ & $3.67(0.07)$ & $4.09(0.07)$ & $+0.42 *$ & $3.55(0.09)$ & $4.08(0.10)$ & $+0.53 *$ & $P=0.25$ \\
\hline $\begin{array}{l}\text { Group work was helpful to establish a study/ } \\
\text { support group in the course }\end{array}$ & $2.88(0.11)$ & $3.24(0.10)$ & $+0.36 *$ & $2.66(0.13)$ & $2.96(0.14)$ & $+0.30 *$ & $P=0.43$ \\
\hline \multicolumn{8}{|c|}{$\begin{array}{l}\text { Note: For each survey response the results are presented as average score (SEM). The survey scale for these questions was from I-5, wherein I indicated the } \\
\text { lowest level of agreement and } 5 \text { indicated the highest level of agreement. The asterisk }(*) \text { indicates a statistically significant difference }(p \leq 0.05) \text { between } \\
\text { the average score from the Pre- and Post-GW Survey questions (i.e., Post-GW - Pre-GW Survey). Differences between the face-to-face and online course } \\
\text { formats are shown with the p-value. }\end{array}$} \\
\hline
\end{tabular}


within the face-to-face course format. The magnitude of the change over the academic semester for all other group dynamics parameters did not differ between course formats $(p>0.05)$.

In both the face-to-face and DE course formats as a result of utilizing the Group Work Contract students reported increased agreement that the distribution of work was equitable between all group members and decreased agreement with needing to complete the majority of the work themselves $(p<0.05)$. The magnitude of the improvement in students' perception that they completed the majority of the work within their group was I.5-fold higher in the DE course format compared to the improvements reported by students in the face-to-face course format $(p=0.0 \mathrm{I})$.

The use of a Group Work Contract improved students' perceptions and approaches towards communication while conducting GW, which was apparent in both the face-to-face and DE course formats where students reported improvements such as i) having frequent or regular group communication approaches, ii) experiencing fewer problems, such as interpersonal disputes or incomplete work, and iii) working collaboratively to solve problems $(p<0.05)$. Interestingly, the magnitude of the improvements in these communication parameters during the academic semester did not differ between course formats $(p>0.05)$. As an additional communication benefit, students in both course formats reported increased engagement with assignment group members to help form a study or support group within the course $(p<0.05)$, an outcome that may be particularly useful for DE students who are working remotely.

\section{Differences in students' methods of communication while conducting $\mathrm{GW}$ in the face-to-face and online DE course formats}

The method of communication utilized by students was significantly different between course formats. Students in the DE course were learning remotely and only $6 \%$ of communication between group members occurred physically in person whereas $94 \%$ of their communication between group members utilized an online communication platform. This is in contrast with the faceto-face course format wherein students were able to physically meet to discuss and work on the group assignment in the course, yet despite this only $52 \%$ of group communication occurred in person and $48 \%$ of communication was conducted online. The types of online communication platforms utilized by students in the face-to-face and DE course formats are shown in Table 2 . In both courses, the majority of online communication was conducted through messaging via Facebook, text message and group messaging apps and email $(86 \%$ combined in the face-toface and $70 \%$ combined in the DE course formats), whereas video conferencing platforms such as Zoom and Microsoft Teams were only utilized by $1 \%$ of students in the face-to-face course and $4 \%$ of students in the DE course formats.Additionally, communication within Courselink, which is the platform for the designated course site for each course was utilized by only $2 \%$ of students in the face-to-face course and $4 \%$ of students in the DE course formats.

\section{Changes in the outcomes of GW within the face-to-face and online DE course formats}

Students' perceptions of the outcomes associated with GW were improved following the implementation of a Group Work Contract, as shown in Table 3. In both the face-to-face and DE
Table 2. Distribution of online communication formats used during GW in face-to-face and DE course formats

\begin{tabular}{|c|c|c|}
\hline & Face-to-Face Format & DE Format \\
\hline \multicolumn{3}{|l|}{ Communication Format } \\
\hline Facebook & $42 \%(n=7 I)$ & $41 \%(n=43)$ \\
\hline Email & $15 \%(n=25)$ & $13 \%(n=\mid 4)$ \\
\hline Text and Group Messaging Apps & $29 \%(n=49)$ & $16 \%(n=17)$ \\
\hline Video Conferencing Platform & $1 \%(n=2)$ & $4 \%(n=4)$ \\
\hline Phone & $0 \%(n=0)$ & $1 \%(n=I)$ \\
\hline CourseLink & $2 \%(n=3)$ & $4 \%(n=4)$ \\
\hline Sharable Group Document & $\mid 1 \%(n=\mid 8)$ & $21 \%(n=22)$ \\
\hline \multicolumn{3}{|c|}{$\begin{array}{l}\text { Note: Text and group messaging apps included WhatsApp, Instagram and } \\
\text { Snapchat. Video conferencing platforms included Zoom and Microsoft } \\
\text { Teams. Sharable group documents included GoogleDocs, Google Drive } \\
\text { and OneDrive. }\end{array}$} \\
\hline
\end{tabular}

course formats following the use of a Group Work Contract students reported increased perceptions of achieving a better outcome (i.e. grade) as a result of working collaboratively versus independently, however, there was no difference in the magnitude of this improvement between course formats. Additionally, students in the DE course format reported learning more as a result of utilizing the Group Work Contract $(p<0.05)$, and although this parameter was improved in the face-to-face course format the magnitude of the change was not statistically significant $(p>0.05)$. Finally, students in both course formats reported that their GW experience overall was improved as a result of utilizing a Group Work Contract $(p<0.05)$, however, the magnitude of this improvement did not differ between course formats.

score (SEM).

\section{Changes in students' anxiety about GW in the face-to-face and online DE course formats}

We determined the degree of anxiety experienced by students when conducting GW, which is presented in Table 4. Students experiencing academic anxiety, the anxiety associated with how GW will impact their grade on the assignment, was significantly improved (i.e., reduced) in the DE course format as a result of utilizing the Group Work Contract $(p<0.05)$, whereas the reduction in academic anxiety in the face-to-face course format was not statistically significant ( $p>0.05)$. Consequently, the magnitude of the reduction in students' academic anxiety about how the group would affect their grade on the assignment was significantly greater in the DE versus face-to-face course format $(p=0.045)$. Social interaction anxiety, the anxiety associated with interacting with other group members and its subsequent impact on the GW process was reduced by utilizing a Group Work Contract in both course formats; however, the magnitude of the reduced social interaction anxiety was similar in the face-to-face and DE course formats. The sources of anxiety observed at baseline in both course formats, assessed by the Pre-GW Survey, are shown in Table 5 . In the face-to-face course format $87 \%$ of students reported experiencing academic anxiety in connection with GW, wherein within this group of students the top three sources of academic anxiety were attributed to i) concerns over the distribution of work and mistrust of their group members work ethic (52\% of students), ii) lack of control during GW (27\%), and iii) difficulty establishing a positive group working dynamic (9\%). Conversely, in the DE course format $95 \%$ of students experienced academic anxiety which was attributed to i) lack of control during GW (52\%), ii) concerns over the distribution of work and mistrust of their group members work ethic (2l\%), and iii) not 
Table 3: Comparison of students' perceptions about GW before and after the use of a GW Contract in both the face-to-face and online course formats

\begin{tabular}{|c|c|c|c|c|c|c|c|}
\hline & \multicolumn{3}{|c|}{ Face-to-Face Format } & \multicolumn{3}{|c|}{ DE Format } & \\
\hline $\begin{array}{c}\text { Survey } \\
\text { Question }\end{array}$ & $\begin{array}{l}\text { Mean Pre-GW } \\
\text { Survey Score }\end{array}$ & $\begin{array}{l}\text { Mean Post-GW } \\
\text { Survey Score }\end{array}$ & \begin{tabular}{|c|} 
Mean \\
Change
\end{tabular} & $\begin{array}{l}\text { Mean Pre-GW } \\
\text { Survey Score }\end{array}$ & $\begin{array}{l}\text { Mean Post-GW } \\
\text { Survey Score }\end{array}$ & \begin{tabular}{|c|} 
Mean \\
Change
\end{tabular} & $\begin{array}{c}\text { Face-to-face } \\
\text { vs DE Format }\end{array}$ \\
\hline \multicolumn{8}{|l|}{ Outcomes } \\
\hline $\begin{array}{l}\text { I achieved a better outcome (e.g. grade) working } \\
\text { collaboratively vs independently }\end{array}$ & $\begin{array}{c}2.87 \\
(0.09)\end{array}$ & $\begin{array}{l}3.39 \\
(0.10)\end{array}$ & $+0.52 *$ & $\begin{array}{l}2.38 \\
(0.11)\end{array}$ & $\begin{array}{l}3.12 \\
(0.13)\end{array}$ & $+0.74^{*}$ & $p=0.09$ \\
\hline $\begin{array}{l}\text { I learned more as a result of collaborating in a } \\
\text { group vs learning independently }\end{array}$ & $\begin{array}{l}3.08 \\
(0.10)\end{array}$ & $\begin{array}{l}3.29 \\
(0.09)\end{array}$ & +0.21 & $\begin{array}{l}2.90 \\
(0.12)\end{array}$ & $\begin{array}{l}-10.1 \\
3.25 \\
(0.11)\end{array}$ & $+0.35^{*}$ & $p=0.18$ \\
\hline $\begin{array}{l}\text { My experience with group work improved as a } \\
\text { result of using the group work contract }\end{array}$ & $\begin{array}{r}3.58 \\
(0.06)\end{array}$ & $\begin{array}{l}4.13 \\
(0.07)\end{array}$ & $+0.55^{*}$ & $\begin{array}{l}3.39 \\
(0.10)\end{array}$ & $\begin{array}{l}3.89 \\
(0.10)\end{array}$ & $+0.50 *$ & $p=0.28$ \\
\hline
\end{tabular}

\begin{tabular}{|c|c|c|c|c|c|c|c|}
\hline & Face & to-Face Format & & & DE Format & & \\
\hline Survey Question & $\begin{array}{l}\text { Mean Pre-GW } \\
\text { Survey Score }\end{array}$ & $\begin{array}{c}\text { Mean Post-GW } \\
\text { Survey Score }\end{array}$ & \begin{tabular}{|l|} 
Mean \\
Change
\end{tabular} & $\begin{array}{c}\text { Mean Pre-GW } \\
\text { Survey Score }\end{array}$ & $\begin{array}{c}\text { Mean Post-GW } \\
\text { Survey Score }\end{array}$ & \begin{tabular}{|l|} 
Mean \\
Change \\
\end{tabular} & $\begin{array}{c}\text { Face-to-face vs } \\
\text { DE Format }\end{array}$ \\
\hline $\begin{array}{l}\text { Academic Anxiety: } \\
\text { I feel anxiety when working on group assignments } \\
\text { about how the group will affect my grade on the } \\
\text { assignment }\end{array}$ & $3.49(0.10)$ & $3.39(0.09)$ & -0.10 & $3.91(0.09)$ & $3.48(0.11)$ & $-0.43^{*}$ & $P=0.045$ \\
\hline $\begin{array}{l}\text { Social Interaction Anxiety: } \\
\text { I feel anxiety about interacting with other stu- } \\
\text { dents when working in a group }\end{array}$ & $3.24(0.10)$ & $2.88(0.1 \mathrm{I})$ & $-0.36^{*}$ & $2.96(0.14)$ & $2.66(0.13)$ & $-0.30 *$ & $P=0.43$ \\
\hline
\end{tabular}

\begin{tabular}{|c|c|c|}
\hline & $\begin{array}{l}\text { Face-to-Face } \\
(n=168)\end{array}$ & $\begin{array}{l}\mathrm{DE} \\
(\mathrm{n}=105)\end{array}$ \\
\hline \multicolumn{3}{|l|}{ Academic Anxiety } \\
\hline \% students experiencing academic anxiety & $87 \%(n=146)$ & $95 \%(n=100)$ \\
\hline \% students not experiencing academic anxiety & $13 \%(n=22)$ & $5 \%(n=5)$ \\
\hline \multicolumn{3}{|l|}{ Primary Source of Academic Anxiety } \\
\hline Distribution of work, concern over "free-loaders" and/or not trusting the work ethic of other group members & $52 \%(n=76)$ & $21 \%(n=2 I)$ \\
\hline Lack of control during group work or influence of others on their grade & $27 \%(n=39)$ & $52 \%(n=52)$ \\
\hline Difficulty establishing a positive group working dynamic & $9 \% \quad(n=13)$ & $8 \% \quad(n=8)$ \\
\hline Negative previous experiences influence current group work perceptions & $7 \% \quad(n=10)$ & $0 \% \quad(n=0)$ \\
\hline Not knowing group members & $5 \% \quad(n=8)$ & $19 \%(n=19)$ \\
\hline \multicolumn{3}{|l|}{ Social Interaction Anxiety } \\
\hline \% students experiencing social interaction anxiety & $54 \%(n=9 \mid)$ & $45 \%(n=47)$ \\
\hline \% students not experiencing social interaction anxiety & $46 \%(n=78)$ & $55 \%(n=58)$ \\
\hline \multicolumn{3}{|l|}{ Primary Source of Social Interaction Anxiety } \\
\hline Not knowing all group members & $56 \%(n=5 I)$ & $87 \%(n=4 I)$ \\
\hline Lack motivation, cooperation or communication between group members leading to not completing their work & $17 \%(n=15)$ & $9 \% \quad(n=4)$ \\
\hline Worried about conflict or disrespectful group members & $13 \%(n=12)$ & $0 \% \quad(n=0)$ \\
\hline Concerned about contributing their ideas or lack confidence in their knowledge & $13 \%(n=12)$ & $4 \% \quad(n=2)$ \\
\hline Influence on the assignment outcome & $1 \%(n=I)$ & $0 \% \quad(n=0)$ \\
\hline
\end{tabular}

knowing their group members (19\%). The proportion of students reporting experiencing social interaction anxiety when conducting GW was $54 \%$ in the face-to-face course format and $45 \%$ in the DE course format. In both course formats the primary source of social interaction anxiety was attributed to students not knowing their group members, which was reported by $56 \%$ of students in the face-to-face course format and $87 \%$ of students in the DE course format.

\section{DISCUSSION}

The current study assessed the influence of a Group Work Contract to facilitate the GW process for students conducting a collaborative group assignment while enrolled in a third year nutritional science course. These outcomes were compared between two courses, one a traditional face-to-face format and the other DE. Following the implementation of the Group Work Contract, students in both course formats reported an improvement in their attitudes towards and experiences while conducting GW, which included categories of outcomes such as i) an equitable distribution of effort between group members, ii) greater reliability of group members, iii) improved communication with fewer interpersonal disputes between group members, and iv) improved group dynamics such as working collaboratively to solve problems and establishing positive working relationships that were inclusive and respectful (Table I). Subsequently, students in both course formats reported that the Group Work Contract improved their experience while conducting GW and students achieved a better outcome (i.e. grade) by working collaboratively (Table 3). There was an extremely high prevalence of academic and social anxiety at the outset of the GW process, however, students reported experiencing a reduction in feelings of social interaction anxiety associated with GW in both course formats, whereas only students in the DE course showed a significant reduction in academic anxiety associated with $\mathrm{GW}$ following the implementation of a Group Work Contract (Table 4). Collectively, there were minimal differences observed between the outcomes in the two course formats, thereby demonstrating the reproducible influence of the Group Work Contract to improve students' perceptions and experiences while conducting GW. 
Establishment of effective group dynamics is necessary for conducting GW and facilitates a positive learning experience (Brownlee \& Motowidlo, 20II). The Group Work Contract promoted the perception of positive group dynamics in both course formats resulting in the formation of groups with positive working relationships, group members that were reliable, functioned in an inclusive and respectful manner and were comprised of group members that established positive working relationships. The magnitude of the improvement in group dynamics was similar between course formats with the exception of establishing positive working relationships with group members, which was more significantly improved in the DE course; however, these students started with lower perceptions of this element of group dynamics compared to the students in the face-to-face course format. Since working in groups increases the interdependence among group members to merge academic ideas and accomplish a task, there is greater potential for conflict and group members must work cooperatively to manage conflicts, which highlights the importance of social and interpersonal skills required to work collaboratively, be dependable and distribute the workload equally among the group members (Campion et al., 1993; Morgeson et al., 2005). A frequently reported concern about GW is the inequitable distribution of effort between group members (Freeman \& Greenacre, 2010; Janssen et al., 2007; Livingstone \& Lynch, 2000), which can limit the associated benefits of collaboration (Johnson \& Johnson, 2009). In both course formats the use of the Group Work Contract increased students' perceptions that the work was distributed equitably between group members, and consequently, there was a reduction in students' perceptions that they were required to complete the majority of the work, although the magnitude of this reduction was greater in the DE course format. Moreover, there were improvements in students' perceptions of working collaboratively to solve problems, and consequently, students reported experiencing fewer problems such as interpersonal disputes while conducting GW in both course formats.

Effective communication underlies successful group learning dynamics and outcomes (Chang \& Brickman, 2018; Lewis, 2004). GW has been shown to promote the development of effective communication skills (Curșeu et al., 20I2), including both social communication and academic written communication skills. Moreover, GW or collaboration aids in the development of students' communication and interpersonal skills while students learn to behave professionally and work cooperatively (Burdett, 2003; Curșeu et al., 20I2; Morgeson et al., 2005; Volkov \& Volkov, 2007). The Group Work Contract helped facilitate the communication strategies utilized by students, which included an improvement in the frequency of group communication in both course formats. The methods of communication utilized while conducting GW differed between course formats wherein $94 \%$ of communication was online and $6 \%$ was conducted in-person in the DE course. We do not know what percentage of students enrolled in the DE course were also enrolled in other in-person courses at the University, and thus, were available to physically meet group members in person versus those who were learning remotely off-campus in other cities who could not easily meet in-person. Thus, the degree of in-person communication in the DE course may have been impacted by the COVID-19 pandemic wherein the University campus was closed and physical in-person meetings were precluded (Dhawan, 2020; Marinoni et al., 2020). Therefore, it is possible that under other circumstances the percentage of in-person communication in the DE course in non-pandemic impacted semesters may be higher. Conversely, $48 \%$ of communication was conducted online in the face-to-face course despite the ability to physically meet. The preferred online platforms for GW communication/interaction in both course formats were similar and included Facebook, text messaging and group messaging apps, email and sharable documents (Table 2). Interestingly, students preferred to utilize their exiting social networking platforms (Facebook, text messaging and group messaging apps such as WhatsApp, Instagram and Snapchat) for GW online communication, which represented $71 \%$ of communication in the face-to-face course and $57 \%$ of communication in the DE course. These asynchronous forms of communication lack visual or auditory cues which may lead to a perception of impersonal communication within the group (Purvanova, 2013), and can present a difficulty in building new relationships in comparison to in-person communication (Pauleen \& Yoong, 200I). Interestingly, both the Courselink site (designated for each course) and video conferencing platforms for online meetings (e.g. Zoom and Microsoft Teams) were underutilized by students in both course formats despite video conferencing being part of a modern communication network in the workplace (Attaran, 2019).

Anxiety is the most commonly reported emotion experienced by students in higher education (Pekrun et al., 2002), which can have negative effects on student learning (Akgun \& Ciarrochi, 2003; Barthelemy et al., 20 I5; England et al., 2019; Witt et al., 20 I4; Zusho et al., 2003). Consistent with this observation, $87 \%$ of students in the face-to-face course and $95 \%$ of students in the DE course reported experiencing academic anxiety, while $54 \%$ of students in the face-to-face and $45 \%$ of students in the DE course reported experiencing social anxiety at baseline (i.e., in the Pre-GW Survey, Table 5). Student anxiety about GW assignments, in particular to the impact of other students on their grade (Butt, 2017; Chang \& Brickman, 2018; Cooper et al., 2018), is common and some students may withdraw from the group and miss out on the benefits associated with the group learning activity (Brigati et al., 2020). In the DE course format the use of the Group Work Contract significantly reduced feelings of academic anxiety (i.e., the anxiety associated with the impact of GW on their grade) compared to students in the face-to-face course format (Table 4). In the Pre-GW Survey where there was a very high baseline level of students reporting feeling academic anxiety associated with GW (87\% of face-to-face students and $95 \%$ of DE students), the primary source could be attributed to concerns over the i) distribution of work among group members, ii) lack of control during GW or influence of others on their grade, and iii) difficulty establishing a positive group dynamic (Table 5), which were accounted for in the Group Work Contract.Additionally, in the DE course, where students were in instructor-selected groups, 19\% of students reported that not knowing their group members was the primary source of academic anxiety they experienced. Conversely, in both course formats the use of the Group Work Contract reduced students' perceptions of social interaction anxiety (i.e., the anxiety associated with interacting with other students while working in a group) (Table 4).Although fewer students reported experiencing this type of anxiety (54\% in the face-to-face and $45 \%$ in the DE course format) the underlying source of this anxiety in the DE course was not knowing their group members (accounting for $88 \%$ of responses), whereas in the face-to-face course format the sources of social interaction anxiety were divided between not knowing their group members and concerns about the group dynamic or possible conflicts between group members (accounting for $86 \%$ of responses combined) (Table 5). Therefore, students' perceptions of anxiety conducting GW associated with not know- 
ing the other group members highlights a critical element of the student learning experience, which could be taken into consideration by instructors when designing GW assignments and the formation of either student-selected or instructor-selected groups. It is important to note that apart from anxiety associated with not knowing their group members the majority of the students' social interaction anxiety concerns were addressed through the use of a Group Work Contract. Despite feelings of anxiety and $97 \%$ students in the DE course and $32 \%$ of students in the faceto-face course not knowing any of their group members, it is important to note that students in both course formats reported achieving a better outcome as a result of working collaboratively and that their experience with GW was improved as a result of using the GW contract (Table 3).Anxiety is frequently attributed to being a negative academic or achievement emotion (Pekrun et al., 2002) resulting in negative self-evaluation and expectations (Strack et al., 2017), however, the experience of anxiety can also be beneficial for students' performance by serving as a motivator (Strack et al., 20I7; Strack \& Esteves, 20I5), which was not assessed in the current study. Future studies should determine how students perceive anxiety (e.g. as debilitative or beneficial) along with an assessment of other academic emotions (both positive and negative).

Prior research has shown that students who partake in GW for an online course tend to be less satisfied with the overall experience, and have a more negative perception, than those who perform GW in the face-to-face format (Smith et al., 20I I). There are some notable differences between the face-to-face and DE course formats and the students enrolled in those courses in the present study, which may help to explain some of the discrepancies in their response to the use of a Group Work Contract. First, the nature of the course format is different, wherein synchronous learning occurs during in-person courses, and asynchronous learning occurs in online DE courses, in which optimal student learning and success in the course is associated with students who are adept at independent learning (Brubacher \& Silindar, 2019; Lei \& Gupta, 2010; Zhu et al. 2020). Secondly, student proximity to previous learning experiences was slightly different, wherein the majority of students (66\%) in the face-to-face course format (offered in the fall semester) were in their fifth semester study, whereas in the DE course (offered in the winter semester) $59 \%$ of students were in their fourth semester of study. Students in both course formats were in proximity to the GW intensive learning experiences such as those in the first year biology curriculum at the University of Guelph (Husband et al., 20I5; Murrant et al., 20I5) Thirdly, there was a difference between course formats in the selection of group members, namely instructor-selected groups in the DE course and student-selected groups in the face-to-face course format. Typically when students are able to select their groups they base this decision on pre-existing friendships and this familiarity is associated with improved communication, cooperation and satisfaction with the outcome of GW (Bacon et al., 1999; Chapman et al., 2006; Hassaskhah \& Mozaffari, 20I5; Mahenthiran \& Rouse, 2000; Mushtaq et al., 2012; Russell, 2010). However, there can be challenges with remaining on task while conducting GW (Hassaskhah \& Mozaffari, 20I5; Mitchell et al., 2004;) and lower acquisition of skills (Basta, 20II) compared to instructor-assigned groups. Despite negative initial reactions to instructor-assigned groups, a functional group dynamic is usually achieved with satisfactory cooperation resulting in a positive outcome overall
(Hassaskhah \& Mozaffari, 20I5; Hilton \& Philips 2008;).Thus, the anxiety associated with not knowing group members decreases over time as group members begin to know each other and their work ethics (Hilliard et al., 2020), a process that can be facilitated by the use of a Group Work Contract. Overall, the outcomes of conducting GW were similar between the face-to-face and DE course formats, with the exception of students in the DE course having an increased perception of learning more as a result of working collaboratively versus independently. This may reflect the fundamental difference between the course formats wherein students in the DE course are learning asynchronously and independently, and therefore, engaging in GW and interacting with other students in the course may have helped stimulate students engagement in the course and helped build a sense of community between students (Summers et al., 2005; Young \& Bruce, 20I I).

There are several implications of this research for teaching practice. Firstly, the utilization of a Group Work Contract at the outset of the GW project in either a face-to-face or DE course format, which should include i) the equitable distribution of effort between members, ii) a communication strategy and timeline for completing each task, iii) group conduct expectations, and iv) a plan for conflict resolution. Secondly, the use of the Group Work Contract may be particularly useful in DE courses, wherein there were significant improvements in helping students establish positive working relationships with group members, distributing the workload among group members, and reducing academic anxiety. Thirdly, it is important for instructors to be aware of the high degree of anxiety that is experienced by students surrounding GW assignments and to take steps to mitigate that anxiety. Fourthly, when mitigating GW anxiety, instructors should consider how groups are formed (i.e., groups comprised of student-selected versus instructor-selected members) and acknowledge the contribution of not knowing the other group members to students anxiety about GW. Finally, instructors should encourage the use of course designated sites such as Courselink for GW, rather than social networking sites, in order to build professional skills to prepare students for the workplace.

\section{LIMITATIONS}

It should be noted that there are many styles of online DE courses, which may include synchronous online lectures or a blended approach wherein the course contains a synchronous component. Therefore, the results from the current study in the DE course may not extend to all online learning course formats. In the current study all students were required to complete the Group Work Contract; therefore, there was no control group in either course format that completed the GW assignment and completed the GW surveys. The GW survey questions were specifically related to the use of a Group Work Contract; however, students were still required to complete an anonymous peer-evaluation of their group members, which may influence students' approaches towards conducting GW. As such, it would be interesting to determine student's perceptions of GW dynamics and anxiety i) without either the Group Work Contract or the peer-evaluation, ii) the Group Work Contract alone, and iii) the anonymous peer-evaluation alone. Additionally, it would be interesting to determine how both students perceptions of GW and anxiety about GW correlated with their final grade on the assignment. This was not assessed in the current study because we did not have participant consent to access their assignment 
grades for research purposes. Finally, there was a slight difference between the face-to-face and DE course formats in the average students' semester of study within the eight semester undergraduate program. The majority of students in the face-to-face course were in their fifth semester, whereas the majority of students in the DE course were in their fourth. Therefore, the students in the two course formats did not have equivalent levels of semesters of undergraduate academic experience which may have influenced the results. The two different course formats are offered in different academic semesters at the University of Guelph, which is a limitation in the study design that is outside of the investigators control. Furthermore, despite sharing the same course content and learning outcomes the face-to-face and DE versions of this course utilize different group assignments (namely the infographic and case study assignment, respectively), which are both worth $10 \%$ of students' final grade in the course. What differed between course formats was the contribution of the group assignment peer-evaluation towards the final grade (namely $5 \%$ in the face-to-face and $2 \%$ in the DE course), and despite being a small difference between course formats, this may have affected how students perceptions of and approaches towards conducting GW. Future studies would benefit from studying students enrolled in the face-to-face and DE course formats within the same semester and conducting identical GW assignments with equivalently weighted GW peer-evaluations contributing to students' final grade in the course.

\section{CONCLUSION}

Collectively, the results from the current study demonstrate the effectiveness of a Group Work Contract to structure the GW learning experience by facilitating the establishment of appropriate group dynamics and communication, resulting in improved outcomes overall, reduced anxiety levels and enhanced student learning in both the face-to-face and DE course formats. For students who have not fully developed the social collaborative and interpersonal skills necessary for effective group dynamics (Campion et al., 1993; Mendo-Lázaro et al., 20 I8; Morgeson et al., 2005; Stewart et al., 2005), the Group Work Contract provides a framework that outlines behaviours and expectations that resulted in students exhibiting greater reliability and developing positive working relationships between group members, such that students worked collaboratively to solve problems in a respectful and inclusive manner.Although peer evaluations have been shown to have a positive effect on students' perceptions about GW (Brooks \& Ammons, 2010; Cestone et al., 2008) and were included in the group assignments associated with this study it is important to note that the survey questions were centered directly on the influence of the Group Work Contract on the overall GW experience. Therefore, the implementation of a Group Work Contract may be beneficial if widely adopted across levels and types of course formats in undergraduate education.

\section{ACKNOWLEDGEMENTS}

This project was supported by the COESP BioEd Research Grant awarded to J.M.M. D.B. was supported by the Scholarship of Teaching and Learning Graduate Research Assistantship from the College of Biological Sciences at the University of Guelph. N.M.C was supported by an Undergraduate Research Assistantship from the University of Guelph. D.M.L was supported by a NSERC graduate scholarship.

\section{REFERENCES}

Akgun, S., \& Ciarrochi, J. (2003). Learned resourcefulness moderates the relationship between academic stress and academic performance. Education Psychology, 23(3), 287-94. https://doi. org/I0.1080/0I4434I032000060I29

Allen, I. E., \& Seaman, J. (20I5). Grade Level: Tracking Online Education in the United States. Babson Survey Research Group. Babson College, 23I Forest Street, Babson Park, MA 02457.

Attaran, M. (2019). Increasing productivity in the information age. Industrial Management, 6I(I), I6.

Auerbach, A., \& Schussler, E. (20I7). Curriculum alignment with "vision and change" improves student scientific literacy. CBE Life Sciences Education, /6(2), ar29. https://doi.org/10.1/87/ cbe. 16-04-0160

Bacon, D. R., Stewart, K.A., \& Silver,W.S. (1999). Lessons from the best and worst student team experiences: How a teacher can make the difference. Journal of Management Education, 23(5), 467-488. https://doi.org/ I 0. I I 77// 05256299902300503

Barthelemy, R. S., Hedberg, G., Greenberg, A., \& McKay, T. (20I5). The climate experiences of students in introductory biology. Journal of Microbiology \& Biology Education, I6(2), I38-I47. https://doi.org/10.1 I28/jmbe.v16i2.921

Basta, J. (20II). The role of the communicative approach and cooperative learning in higher education. Facta Universitatis Series: Linguistics and Literature, 9(2), I25-I43.

Bol, L., \& Garner, J. K. (20I I). Challenges in supporting self-regulation in distance education environments.Journal of Computing in Higher Education, 23(2), I04- I23. https://doi.org/10.1007/ s I 2528-0 I I-9046-7

Brigati, J. R., England, B. J., \& Schussler, E. E. (2020). How do undergraduates cope with anxiety resulting from active learning practices in introductory biology? PLOS ONE, 15(8), I-23. https://doi.org/10.137//journal.pone.0236558

Brooks, C.M.,\&Ammons,J.L.(20I0). Free Riding in Group Projects and the Effects of Timing, Frequency, and Specificity of Criteria in Peer Assessments. Journal of Education for Business, 78(5), 268-272. https://doi.org//0.1080/088323203095986/3

Brownlee,A. L., \& Motowidlo, S. J. (20I I). Effects of accountability to group members and outcome interdependence on task behavior and interpersonal contextual behavior. Journal of Organizational Psychology, I I ( I), 24-35

Brubacher, M., \& Silinda, F. (20I9). Enjoyment and Not Competence Predicts Academic Persistence for Distance Education Students. International Review of Research in Open and Distributed Learning, 20(3), I65- I79. https://doi.org/ /0.19173/irrodl. v20i4.4325

Burdett, J. (2003). Making groups work: University students' perceptions. International Education Journal, 4(3), I77-I9I.

Butt, A. (20I7). Quantification of influences on student perceptions of group work. Journal of University Teaching and Learning Practice, I5(5), I- I5. https://doi.org/ 10.2139/ssrn.3001625

Campion, M.A., Medsker, G. J., \& Higgs, A.C. (1993). Relations between work group characteristics and effectiveness: Implications for designing effective work groups. Personnel Psychology, 46(4), 823-850. https://doi.org/ I 0. I I I I/j. I 744-6570. I 993. tb0157I.x

Cartwright, N. M., Patil P., Liddle D.M., Newton, G., \& Monk, J. M. (202I). Enhancement of professional behaviours and perceptions of critical skill job preparedness through the use of a group work contract in fourth-year nutritional science 
students. International Journal of Higher Education, I0(2), 274l. https://doi.org//0.5430/ijhe.v10n2p27

Cestone, C. M., Levine, R. E., \& Lane, D. R. (2008). Peer assessment and evaluation in team-based learning. New Directions for Teaching and Learning, I I 6, 69-78. https://doi-org.subzero. lib.uoguelph.ca/I0.1002/tl.334

Chang,Y., \& Brickman, P. (20I8). When group work doesn't work: Insights from students. CBE-Life Sciences Education, I7(3), ar52. https://doi.org/10.1 I87/cbe.17-09-0199

Chang, B., \& Kang, H. (2016). Challenges facing group work online. Distance Education, 37(I), 73-88. https://doi.org/I0.1080/0 I5 87919.2016.|I5478|

Chapman, K. J., Meuter, M., Toy, D., \& Write, L. (2006). Can't we pick our own group? The influence of group selection method on group dynamics and outcomes. Journal of Management Education, 30, 557-569. https://doi. org/10.1 I77// 052562905284872

Cooper, K. M., Downing, V. R., \& Brownell, S. E. (2018). The influence of active learning practices on student anxiety in large-enrollment college science classrooms. International Journal of STEM education, 5, 23. https://doi.org/l0.1186/ s40594-0 I 8-0I 23-6

Curșeu, P. L., Janssen, S. E., \& Raab, J. (20/2). Connecting the dots: Social network structure, conflict, and group cognitive complexity. Higher Education, 63(5), 62 I-629. https://doi. org/ 10.1007/s I0734-0 I I-9462-7

Dhawan, S. (2020). Online learning: A panacea in the time of COVID-I 9 crisis. Journal of Educational Technology, 49(I), 5-22. https://doi.org/ I0.I I77/00472395209340I8

Ekmekci, E. (20I5). Distance-education in foreign language teaching: evaluations from the perspectives of freshman students. Procedia - Social and Behavioral Sciences, 176, 390-397.https:// doi.org/10.1016/j.sbspro.2015.01.487

England, B. J., Brigati, J. R., Schussler, E. E., \& Chen, M. M. (20I9). Student anxiety and perception of difficulty impact performance and persistence in introductory biology courses. CBELife Science Education, /8(2), I-I3. https://doi.org/10.1 I87/ cbe. I 7-1 2-0284

Eurofound. (2007). Teamwork and high performance work organization. Dublin, Ireland: European Foundation for the Improvement of Living and Working Conditions.

Freeman, L., \& Greenacre, L. (20I0).An examination of socially destructive behaviors in group work. Journal of Marketing Education,33(I),5-I7.https://doi.org/I0.I I 77/02734753 I0389I 50

Gil, F., \& Alcover, C. M. ( 1998). Introduction to group psychology. Madrid: Pyramid.

Gillies, R. M. (2003). The behaviors, interactions, and perceptions of junior high school students during small-group learning. Journal of educational Psychology, 95(I), I37. https://doi. org/10.1037/0022-0663.95.I.137

Hammar Chiriac, E. (20I4). Group work as an incentive for learning-students' experiences of group work. Frontiers in psychology, 5, 558. https://doi.org// 0.3389/fpsyg.2014.00558

Hassaskhah, J., \& Mozaffari, H. (20I5) The impact of group formation method (student-selected vs. teacher-assigned) on group dynamics and group outcome in EFL creative writing. Journal of Language Teaching and Research, 6(I), I47-I56. http://dx.doi.org//0.17507;jltr.060I.I8

Hassenburg, A. (2009). Distance education versus the traditional classroom. Berkeley Scientific Journal, I3(I), 7-I0.
Hilliard, J., Kear, K., Donelan, H., \& Heaney, C. (2020). Students' experiences of anxiety in an assessed, online, collaborative project. Computers \& Education, 143, 103675. https://doi. org/10.1016/j.compedu.2019.103675

Hilton, S., \& Philips, F. (2008). Instructor-assigned and student-selected groups: A view from inside. Issues in Accounting Education, 25(I), I5-33. https://doi.org//0.2308/iace.2010.25.I.I5

Husband, B. C., Bettger,W. J., Murrant, C. L., Kirby, K.,Wright, P.A., Newmaster, S. G., ...Wolf, P. (20I5).Applying a linked-course model to foster inquiry and integration across large firstyear courses. Canadian Journal of Higher Education (1975), 45(4), 244-260.

Janssen, J., Erkens, G., Kanselaar, G., \& Jaspers, J. (2007). Visualization of participation: Does it contribute to successful computer-supported collaborative learning? Computers and Education, 49(2007), 1037-1065. https://doi.org/10.1016/j. compedu.2006.01.004

Johnson, D. W., Johnson, R. T., \& Smith, K. (2007). The state of cooperative learning in postsecondary and professional settings. Educational Psychology Review, 19(2007), 15-29. https:// doi.org/ I 0.1007/s I0648-006-9038-8

Johnson D.W., \& Johnson R.T. (2009). An educational psychology success story: Social interdependence theory and cooperative learning. Educational Researcher, 38(5), 365-379. https:// doi.org/10.3102/0013189X09339057

Le, H., Janssen, J., \&Wubbels, T. (2016). Collaborative learning practices: Teacher and student perceived obstacles to effective student collaboration. Cambridge Journal of Education, 48(I), I03-I 22. https://doi.org/ / 0.1080/0305764X.2016.1259389

Lei, S., \& Gupta, R. (2010). College Distance Education Courses: Evaluating Benefits and Costs from Institutional, Faculty, and Student Perspectives. Education (Chula Vista), I 30(4), 6I 6-63 I.

Lewis, K. (2004). Knowledge and performance in knowledge-worker teams: A longitudinal study of transactive memory systems. Management Science, 50(II), I5I9-1533. https://doi.org// 0.1287/mnsc. 1040.0257

Li, M., \& Campbell, J. (2008).Asian students' perceptions of group work and group assignments in a New Zealand tertiary institution. Intercultural Education, 19(3), 203-2 16. https://doi. org/ I 0.1080/ I 4675980802078525

Liu, Q., Liu, B., \& Lin, Y. (2019). The influence of prior knowledge and collaborative online learning environment on students' argumentation in descriptive and theoretical scientific concept. International Journal of Science Education, 4 I (2), I 65-I87. https://doi.org// 0.1080/09500693.2018.1545100

Livingstone D., \& Lynch K. (2000). Group project work and student-centered active learning: Two different experiences. Studies in Higher Education, 25(3), 325-345. https://doi. org/I0.1080/7/3696/6I

Mahenthiran, S., \& Rouse, P. J. (2000). The impact of group selection on student performance and satisfaction. Scholarship and Professional Work - Business, 185, 255-265. http://dx.doi. org/l0.1 I08/095 I3540010348043

Marinoni, G., van't Land, H., \& Jensen, T. (2020). The impact of COVID-1 9 on higher education around the world: IAU global survey report. France: International Association of Universities.

Mclnerney, M. J., \& Fink, L. D. (2003). Team-based learning enhances long-term retention and critical thinking in an undergraduate microbial physiology course. Microbiology Education, 4, 3-I2. https://doi.org/ | 0.I | 28/ I 54288 I03X I 4285806229759 
Mendo-Lázaro, S., León-Del-Barco, B., Felipe-Castaño, E., PoloDel-Río, M., \& Iglesias-Gallego, D. (2018). Cooperative team learning and the development of social skills in higher education:The variables involved. Frontiers in Psychology, 9( I536). https://doi.org/l0.3389/fpsyg.2018.01536

Mitchell, S. N., Reilly, R., Bramwell, F. G., Lilly, F., \& Solnosky, A. (2004). Friendship and choosing groupmates: Preferences for teacher-selected vs. student-selected groupings in high school science classes. Journal of Instructional Psychology, $3 I(I), 20$.

Monk, J. M., \& Newton, G. (20I8). Use of scaffolded case study assignment to enhance students' scientific literacy skills in undergraduate nutritional science education: Comparison between traditional lecture and distance education course formats. International Journal of Higher Education, 7(2), 95- 106. https://doi.org//0.5430/ijhe.v7n2p95

Morgeson, F. P., Reider, M. H., \& Campion, M. A. (2005) Selecting individuals in team settings: The importance of social skills, personality characteristics, and teamwork knowledge. Personnel Psychology, 58(3), 583-6II. https://doi.org/I0.IIII/ j. 1744-6570.2005.655.x

Murrant, C. L., Dyck, D. J., Kirkland, J. B., Newton, G. S., Ritchie, K. L., Tishinsky, J. M., . . Richardson, N. S. (20I5). A large, first-year, introductory, multi-sectional biological concepts of health course designed to develop skills and enhance deeper learning. Canadian Journal of Higher Education (1975), 45(4), 42-62.

Mushtaq, R., Murteza, G., Rashid, S., \& Khalid, A. (2012). The influence of group selection method on grades, performance and group outcome. Journal of Basic and Applied Scientific Research, 2(7), 7003-7008.

Pauleen, D. J., \& Yoong, P. (200I). Facilitating virtual team relationships via Internet and conventional communication channels. Internet Research, II(3), 190-202. https:/doi. org/I0.I I08/10662240II0396450

Pauli, R., Mohiyeddini, C., Bray, D., Michie, F., \& Street, B. (2008). Individual differences in negative group work experiences in collaborative student learning. Educational Psychology, 28(I), 47-58. https://doi.org/I0.1080/0 I4434 I070I4I3746

Payne, B. K., Monk-Turner, E., Smith, D., \& Sumter, M. (2006). Improving group work: Voices of students. Education, I 26(3), $44 \mid-448$.

Pekrun, R., Goetz, T., Titz,W., \& Perry, R. P. (2002). Academic emotions in students' self-regulated learning and achievement: A program of qualitative and quantitative research. Educational Psychologist, 37(2), 9/-I05. https://doi.org//0.1207/ SI5326985EP3702 4

Purvanova, R. K. (20I3). Virtual versus Face-to-Face Teams: What Have we Really Learned?. Academy of Management Proceedings, 20/3(I), I74/3. https://doi.org/I0.5465/ ambpp.2013.174I 3abstract

Ribner, N. (1974). Effects of an explicit group contract on self-disclosure and group cohesiveness. Journal of Counseling Psychology, 2 I (2), I I 6-I 20. https://doi.org/ I0.1037/h0036/95

Russell, M. (2010). The formation of effective work groups within an FE classroom. Research in Post-compulsory Education, I5(2), 205-22 I. https://doi.org//0.1080//359674/003790765

Smith, G. G., Sorensen, C., Gump, A., Heindel, A. J., Caris, M., \& Martinez, C. D. (20II). Overcoming student resistance to group work: Online versus face-to-face. The Internet and
Higher Education, 14(2), 121-128. https://doi.org/10.1016/j. iheduc.2010.09.005

Stewart, G. L., Fulmer, I. S., \& Barrick, M. R. (2005). An exploration of member roles as a multilevel linking mechanism for individual traits and team outcomes. Personnel Psychology, 58(2), 343-365. https://doi.org/ I 0. I I I I/j. I 744-6570.2005.00480.x

Strack, J., Esteves, F. (20I5). Exams? Why worry? Interpreting anxiety as facilitative and stress appraisals. Anxiety, Stress, and Coping, 28(2), 205-2/4. https://doi.org//0.1080//06I5806.2 014.931942

Strack, J., Lopes, P., Esteves, F., \& Fernandez-Berrocal, P. (2017). Must we suffer to succeed? When anxiety boosts motivation and performance. Journal of Individual Differences, 38(2), I | 3- | 24. https://doi.org//0.1027/|6|4-000 |/a000228

Summers, J. J., Gorin, J. S., Beretvas, S. N., \& Svinicki, M. D. (2005). Evaluating Collaborative Learning and Community. The Journal of Experimental Education, 73(3), 165-188. https://doi. org/I0.3200/JEXE.73.3.165-188

Volet, S., \& Mansfield, C. (2006). Group work at university: Significance of personal goals in the regulation strategies of students with positive and negative appraisals. Higher Education Research \& Development, 25(4), 34I-356. https://doi. org/ I0. I080/0729436060094730 I

Volkov, A., \& Volkov, M. (2007). Teamwork and assessment: A critique. Journal of Business Education \& Scholarship of Teaching, I (I), 59-64

Volkov, A., \& Volkov, M. (20I5). Teamwork benefits in tertiary education. Education \& Training (London), 57(3), 262-278. https:// doi.org/I0.I I08/ET-02-2013-0025

Wasley, P. (2006). Underrepresented students benefit most from 'engagement.' The Chronicle of Higher Education, 53(I3), p.A39.

Wei, H. C., \& Chou, C. (2020). Online learning performance and satisfaction: do perceptions and readiness matter?. Distance Education, 4I (I), 48-69. https://doi.org/I0.1080/0I5879I9.2 020.1724768

Wilson, K. J., Brickman, P., \& Brame, C.J. (20I8). Group work. CBELife Sciences Education, I7(I), fel. https://doi.org/10.1/87/ cbe. I7-12-0258

Witt, P. L., Schrodt, P., Wheeless, V. E., \& Bryand, M. C. (20I4). Students' intent to persist in college: Moderating the negative effects of receiver apprehension with instructor credibility and nonverbal immediacy. Communication Studies, 65(3), 330-52. https://doi.org/10.1080/105 I0974.2013.8II428

Young, S., \& Bruce, M.A. (20I I). Classroom Community and Student Engagement in Online Courses. Journal of Online Learning and Teaching, 7(2), $219-230$.

Zhang, L., Huang, S., \& Peng,Y. (20I8). Collaboration in integrated project delivery: the effects of trust and formal contracts. Engineering Management Journal, 30(4), 262-273. https://doi. org/10.1080/10429247.2018.1498259

Zhu, Y., Zhang, J., Au, W., \& Yates, G. (2020). University students' online learning attitudes and continuous intention to undertake online courses: a selfregulated learning perspective. Education Technology Research and Development, 68(3), I485I519. https://doi.org/ | 0.1007/s | |423-020-09753-w

Zusho, A., Pintrich, P. R., \& Coppola, B. (2003). Skill and will:The role of motivation and cognition in the learning of college chemistry. International Journal of Science Education, 25(9), |08|-94. https://doi.org// 0.1080/0950069032000052207 


\section{Supplemental Materials: Group Work Contract}

Provide the first and last name of each group member:

We are equally responsible for fulfilment of all the requirements for the completion of this project, which includes selecting the topic, research, writing, meetings, submission, presentation, etc.

Our Task-related Goals and Timelines

We have identified the following specific, measurable, and achievable tasks towards completing this assignment. (Add/delete table rows as necessary)

By signing our initials below, have accepted responsibility for completing these tasks by the dates indicated Fill in the Text Boxes below as a group and add lines as needed

\begin{tabular}{|c|l|l|l|l|}
\hline Task to be Completed & By Whom & Initial Acceptance & Date Due & Done \\
\hline I... & & & & \\
\hline $2 \ldots$ & & & & \\
\hline $3 \ldots$ & & & & \\
\hline Etc... & & & & \\
\hline
\end{tabular}

\section{About Our Relationship}

Group Norms. We consider the following attitudes and behaviours to be important to our group and will strive to uphold these in our work as a group:

E.g. communication, no tardiness, respectful consideration of all ideas, deadlines and completion of tasks are met, ask questions if we are confused about something, help one another if need be as outlined below:

We will make decisions in the group in the following manner:

\section{Guidelines for Communication}

Consider the possible group communication strategies that you might want to use for interacting with your fellow group members (e.g. in-person meetings, email, Skype, Courselink discussion board, social media, etc.). Decide upon and outline your preferred communication approach(es) for how your group members will interact on this project. 
Will your group hold regular meetings to discuss progress on the assignment? If so, please provide the schedule for these meetings (and include the meeting format type e.g. in-person, Skype, etc.). If your group chooses not to hold progress meetings please state this.

\section{Conflict Resolution}

Outline a plan for how your group intends to handle conflicts or situations where the group contract is broken.

If applicable, please add any other information that your group has agreed to that was not included above. If there is nothing else the group wants to add please write "not applicable".

\section{Signatures}

It is a recommended that each individual to initial AGAIN in the case of major revisions (or amendment to the Group Work Contract). Please send a revised version of Group Work Contract to the course instructor.

\begin{tabular}{|l|l|l|l|}
\hline Name of Group Member & Signature & $\begin{array}{c}\text { Date of Revision \& } \\
\text { New Signature }\end{array}$ & $\begin{array}{c}\text { Date of Revision \& } \\
\text { New Signature }\end{array}$ \\
\hline & & & \\
\hline & & & \\
\hline
\end{tabular}

By signing above, we accept responsibility for completing the tasks for the projects 
IJ-SoTL, Vol. 15 [2021], No. 2, Art. 5 